\title{
Application of Markowitz Portfolio Theory to Producing the World Major Field Crops
}

\author{
Natalia Vasylieva \\ Department of Information Systems and Technologies, Dnipro State Agrarian and Economic University, \\ Ukraine
}

\begin{abstract}
Development of growing cereals and oilseeds is a pressing issue for providing global food security and renewable energy. The study deals with applying methods of portfolio theory to mitigate natural and marketing uncertainties emerged from unstable yields and volatile prices for wheat, maize, barley, sunflower, soybeans, and rapeseed. The research outcome based on the utilization of Markowitz meanvariance indicators made possible to evaluate portfolio performances of the world top cereals and oilseeds producers. The study findings at a country level combined econometric forecasting of the crop revenues and modeling optimal portfolios of cereals and oilseeds subject to acceptable trade-offs between risks and expected revenues. The fulfilled calculations with Ukrainian focus clarified farmland allocations under cereal and oilseed crops to underpin biodiversity and keep firm positions in the world markets.
\end{abstract}

\section{Keywords}

Cereals and oilseeds; risk; production portfolio; revenue forecast; Markowitz models.

Vasylieva, N. (2020) "Application of Markowitz Portfolio Theory to Producing the World Major Field Crops", AGRIS on-line Papers in Economics and Informatics, Vol. 12, No. 4, pp. 123-131. ISSN 1804-1930. DOI 10.7160/aol.2020.120409.

\section{Introduction}

The world major field crops are cereals and oilseeds. They are utilized for food, feed, and bio-fuel production. As of 2019, the prime cereal crops like wheat, rice, maize, and barley occupied 214.8, 167.1, 193.7, and 48 million hectares of farmland around the world and were cultivated in 123, 117, 168, and 104 countries respectively. Similarly, the prime oilseed crops such as sunflower, soybeans, and rapeseed covered $26.7,124.9$, and 37.6 million hectares of the world arable land in 73, 99, and 65 countries (FAOStat, 2020).

At the same time, agriculture is a risky business. It implies that farmers have to meet the challenges of output uncertainty caused by the natural factors and price volatility affected by fluctuations of the market supply and demand. The most promising tool to facilitate this issue is a portfolio approach. In case of the agricultural sector, portfolio production can measure a risk, predict revenue, and allocate a restricted resource of farmland on different assets like cash crops. Developing such optimal win-win strategies will comply with the environmental, social, and economic goals of maintaining agricultural biodiversity, providing the global food security in view of the accelerated population growth, and gaining competitive advantages in the domestic and international agricultural markets. Given the pressing aspects of portfolio production of the world major field crops, it is worth a separate thorough scientific study.

Creating risk-efficient operating plans and strategies is a key point in contemporary agriculture. Farmers around the globe are exposed to production, marketing, financial, legal, and personnel risks. Science proposes a wide variety of means and tools to handle such uncertainties. But the most fruitful risk-management decisions are those adjusted to specific agricultural products (Broll et al., 2013).

The European cropping pattern includes the above listed world major cereals and oilseeds except for rice. Given the Ukrainian research focus, this investigation considered wheat, maize, barley, sunflower, soybeans, and rapeseed. Advanced economics of their production, processing, marketing, and utilization was revealed in numerous comprehensive studies, in particular by Carver (2009), Danforth (2011), Elfson (2011), 
Martinez-Force et al. (2015), Johnson et al. (2015), and Gunstone (2004).

Villanueva et al. (2017) clarified that the witnessed biodiversity within the groups of cereals and oilseeds have a positive impact on crops resilience and adaptability to the ongoing climate change. Besides, Brussaard et al. (2010), Frison et al. (2011) indicated importance of biodiversity in providing food security via preventing declines in yields of the core staple crops. In case of Ukraine, biodiversity contributed to robust food security by cereals and oilseeds, unlike other industries of the national agriculture (Vasylieva, 2018; Vasylieva, 2019).

Mathematical models developed by Brummer et al. (2016), Haile et al. (2016), Santeramo and Lamonaca (2019) offered accurate and convincing evidence that risks in supplies dependent on yield fluctuations strongly affect price volatility in cereals and oilseeds markets. In other words, it is crucial to allocate farmland under a mix of crops to match both natural and market conditions (Skrypnyk et al., 2018; Ramankutty et al., 2018).

In this regard, the most appropreate mathematical apparatus is the portfolio concept intended to assist in selecting weights of assets to mitigate possible losses (Kolm et al., 2014). Such approach demonstrates reliable results in modelling diversified crop production. In particular, based on the assumption that "typically, risk in the farm income arises from risk in revenue", Mumey et al. (1992, p. 71) developed models of reducing revenue risk experienced by the wheat, barley, and canola producers at the local level. Barkley et al. (2010) examined a portfolio of wheat varieties directed at increasing yields, shrinking risk and enhancing profitability. Radulescu et al. (2014) elaborated optimal portfolios under minimum environmental and financial risks or maximum expected returns from growing wheat, corn, barley, sunflower, and rapeseed. Recent findings on this topic included models on mean-variance planning for crop farms (Toth et al., 2016).

However, the world production portfolios of the most demanded cereals and oilseeds need an updated comparison which entails options of the optimal crop portfolios applicable at a country level. In light of the agricultural resources and potentials, the latter was conducted for Ukraine. With this research objective, the study was divided into three tasks:

- to implement Markowitz mean-variance indicators to track progress in performing production portfolios of the world major cereals and oilseeds;

- to forecast fluctuations of revenues from wheat, maize, barley, sunflower, soybeans, and rapeseed caused by unstable yields and price volatility in Ukraine; and

- to utilize Markowitz models for cereals and oilseeds to calculate their production portfolios subject to an acceptable trade-off between risk and expected revenue.

\section{Materials and methods}

To cope with the task 1 , this research employed the mean-variance fundamentals of Markowitz portfolio theory (Markowitz, 2010). In more detail, $\mathrm{N}$ was a quantity of crops in an evaluated portfolio;

$\mathrm{W}_{\mathrm{i}}$ designated a portfolio share of each crop subject to $\mathrm{W}_{\mathrm{i}} \geq 0, \mathrm{i}=1, \ldots, \mathrm{N}, \sum_{\mathrm{i}=1}^{\mathrm{N}} \mathrm{W}_{\mathrm{i}}=1$;

$\mathrm{T}$ defined an analyzed time frame; and

$\mathrm{X}_{\mathrm{t}}^{\mathrm{i}}$ referred to an annual revenue from crop $i$ at a point in time $t, i=1 \ldots N, t=1, \ldots, T$.

It made possible to compare portfolio performance among the world top crop producers via expected portfolio revenue (EPR) and portfolio risk (PR) built on the logarithmic indices of crop revenue relative to values in the preceding year:

$Z_{t}^{i}=\operatorname{Ln}\left(X_{t}^{i} / X_{t-1}^{i}\right), t=2, \ldots, T$,
$Z^{i}=\sum_{t=2}^{T} Z_{t}^{i} /(T-1), i=1, \ldots, N$.

In this fashion, the named portfolio indicators were calculated as follows:

$$
\begin{aligned}
& E P R=\sum_{i=1}^{N} W_{i} \cdot Z^{i} \\
& P R=\sqrt{\sum_{i=1}^{N} \sum_{j=1}^{N}\left(W_{i} \cdot W_{j} \cdot \sum_{t=2}^{T}\left(\left(Z_{t}^{i}-Z^{i}\right) \cdot\left(Z_{t}^{j}-Z^{j}\right)\right) /(T-1)\right)} .
\end{aligned}
$$

In addition, an indicator of the present portfolio revenue (PPR) illuminated a current output in absolute terms like

$\mathrm{PPR}=\sum_{\mathrm{i}=1}^{\mathrm{N}} \mathrm{W}_{\mathrm{i}} \cdot \mathrm{X}_{\mathrm{T}}^{\mathrm{i}}$.

The panel data intended for the task 1 involved time-series of revenues from the world major portfolio crops by top countries.

A methodical background to the task 2 was econometrics (Greene, 2007; Studenmund, 2016). It was focused on capturing trend and cycle 
components of dynamics in crop revenue. For such reason, the offered regression incorporated linear and sinusoidal components such as

$X(t)=A_{0}+A_{1} \cdot t+A_{2} \cdot \sin \left(A_{3}+A_{4} \cdot t\right)$.

Here $X(t)$ denoted a calculated crop revenue (in $\$$ per hectare) associated with a time variable $t$. The numerical regression coefficients $A_{0}-A_{4}$ were found through the least squares method applied to the time-series data concerning the analyzed major field crops, i.e.

$\sum_{t=1}^{T}\left(X_{t}-\left(A_{0}+A_{1} \cdot t+A_{2} \cdot \sin \left(A_{3}+A_{4} \cdot t\right)\right)\right)^{2} \rightarrow \min$.

As before, $T$ denoted a time frame, and $\mathrm{X}_{\mathrm{t}}$ was a real crop revenue referred to the observation $t$. The regression coefficients allowed comparing dynamics in different crops. Namely, the coefficient $A_{1}$ described an annual change in a revenue trend. Meanwhile, the coefficient $A_{2}$ revealed the revenue volatility via a cycle amplitude.

R-squared and F-test verified the regression applicability to forecasting crop revenue over the future periods. In case of inadequate accuracy of calculations, the utilized least squares method should be replaced by its advanced modification.

To arrange a trade-off between the expected portfolio revenue and portfolio risk, the research task 3 dealt with both maximum and minimum Markowitz models (Prigent, 2007). In compliance with the previous identifications, $W_{1}, i=1, \ldots, N$ were the model variables associated with the sought shares of crops in production portfolios. The given lower bounds to the share of each crop enabled to promote biodiversity assuming that

$\mathrm{S}_{\mathrm{i}}>0, \mathrm{i}=1, \ldots, \mathrm{N}$, and $\sum_{\mathrm{i}=1}^{\mathrm{N}} \mathrm{S}_{\mathrm{i}}<1$.

The models input data were obtained from the tasks 1 and 2. In particular, the values of $E P R_{\text {min }}$ and $P R_{\max }$ introduced the acceptable levels of minimal expected portfolio revenue (1) and maximal portfolio risk (2).

Thus, the maximum Markowitz model translated into

$\mathrm{EPR} \rightarrow \max$

subject to $\mathrm{W}_{\mathrm{i}} \geq \mathrm{S}_{\mathrm{i}}, \mathrm{i}=1, \ldots, \mathrm{N}, \sum_{\mathrm{i}=1}^{\mathrm{N}} \mathrm{W}_{\mathrm{i}}=1$,

$\mathrm{PR} \leq \mathrm{PR}_{\max }$

The minimum Markowitz model looked like

$\mathrm{PR} \rightarrow \min$ subject to $\mathrm{W}_{\mathrm{i}} \geq \mathrm{S}_{\mathrm{i}}, \mathrm{i}=1, \ldots, \mathrm{N}, \sum_{\mathrm{i}=1}^{\mathrm{N}} \mathrm{W}_{\mathrm{i}}=1$,

$\mathrm{EPR} \geq \mathrm{EPR}_{\min }$.

Applications of the formulated Markowitz models under different scenarios can ground the farmers' strategies on diminishing portfolio risks in times of recession or increasing expected portfolio revenues in times of economic expansion. As such, the calculated shifts in production portfolios will provide the national agricultural authorities with the objective forecasts about country ranks among the world top rivals in cereals and oilseeds markets.

\section{Results and discussion}

The described research methodology entailed the relevant empirical outcomes presented in this section.

\section{Global crop portfolios}

Hereafter there was intended for wheat, maize, and barley in the group of cereals or for sunflower, soybeans, and rapeseed in the group of oilseeds. To synchronize outcomes of the task 1 with further results referring to Ukraine, the study time frame covered the period of 1996 to 2018 started from launching Ukrainian national currency. It stipulated $\mathrm{T}=23$.

Consistent with Mumey et al. (1992), the presented research examined a portfolio risk in expected revenue. To define the latter, a comprehensive panel data to the task 1 contained yields and farmgate prices for wheat, maize, barley, sunflower, soybeans, and rapeseed by country (FAOStat, 2020). The conducted world comparison considered countries which practice production portfolios and occupy over $1 \%$ of the total harvested area under at least 2 crops amongst the analyzed cereals and oilseeds.

As such, Table 1 encompassed 20 countries which were engaged in cereals production portfolios and accumulated $83.1 \%, 64.3 \%$, and $78.8 \%$ of the global farmland under wheat, maize, and barley respectively. Overall, it means a strong commitment of cereals growers to implementing portfolios. Besides, Indonesia, Nigeria, and the Philippines also practiced crop portfolios cultivating $9.6 \%, 2 \%$, and $2.9 \%$ of the total farmland under rice as well as $2.9 \%, 2.5 \%$, and $1.3 \%$ of the world arable land under maize. Similarly, Pakistan occurred to comprise $1.7 \%$ of rice and $4.1 \%$ of wheat total harvested areas. But given the rice components, the described portfolios were beyond the study focus. 
A thorough insight on the indicators in Table 1 revealed different features and priorities of the listed countries. Indeed, China, India, Ethiopia, and Iran are the $1^{\text {st }}, 2^{\text {nd }}, 12^{\text {th }}$, and $18^{\text {th }}$ countries by population. In light of providing food security to meet high steady domestic demands, they demonstrated relatively low risks and high absolute revenues. It is also worth mentioning that India and China are the top growers of rice with $26.6 \%$ and $18.1 \%$ of its total harvested area. In compliance with Rude and An (2015), the largest cereals exporters such as France, Germany, and the USA had moderate portfolio risks paired with average expected portfolio revenues offset by high revenues in absolute terms. The Argentinean, Brazilian, Canadian and Ukrainian portfolio performance appeared to be quiet similar and promising. To some extent, Poland, Romania, Spain and Turkey illustrated opposite priorities in accepting risks justified by higher revenues. In spite of large scale cereals production, Australia, Kazakhstan, and Russia were merged by risky and inefficient results. The worst portfolio performance was found in Algeria and Morocco which should revise their agricultural strategies and improve portfolio indicators of EPR (1), PR (2), and PPR (3).

Table 2 reported data about 10 countries which were involved in oilseeds production portfolios and accumulated $74.6 \%, 63.1 \%$, and $75.4 \%$ of the world harvested areas under sunflower, soybeans, and rapeseed respectively.

Table 2 displayed that the oilseeds portfolio of China dominated over that of India by most indicators. The top world exporters such as France and the USA had similarly balanced oilseeds portfolios. The strongest risk acceptance emerged in Romania that presented an opposite operational priority compared to Canada. The Ukrainian oilseeds portfolio showed better relative indicators of EPR (1) and PR (2) than those in Argentina but, unfortunately, did not gain by PPR (3). As before, despite large occupied farmlands, Kazakhstan and Russia had risky and inefficient oilseeds portfolios in absolute terms.

\begin{tabular}{|c|c|c|c|c|c|c|}
\hline \multirow{2}{*}{ Country } & \multicolumn{3}{|c|}{ Share $(\%)$ in the World Farmland under } & \multirow{2}{*}{$\begin{array}{c}\text { Expected } \\
\text { Portfolio } \\
\text { Revenue (\%) }\end{array}$} & \multirow{2}{*}{$\begin{array}{c}\text { Portfolio Risk } \\
(\%)\end{array}$} & \multirow{2}{*}{$\begin{array}{c}\text { Present } \\
\text { Portfolio } \\
\text { Revenue (\$/ha) }\end{array}$} \\
\hline & Wheat & Maize & Barley & & & \\
\hline Algeria & 1.0 & 0.0 & 2.7 & 1.8 & 29.4 & 581.3 \\
\hline Argentina & 2.7 & 3.7 & 2.5 & 2.1 & 22.1 & 801.6 \\
\hline Australia & 5.1 & 0.0 & 8.6 & 0.2 & 31.5 & 414.5 \\
\hline Brazil & 1.0 & 8.3 & 0.2 & 3.4 & 22.1 & 765.5 \\
\hline Canada & 4.6 & 0.7 & 5.0 & 2.9 & 23.6 & 693.9 \\
\hline China & 11.3 & 21.7 & 0.8 & 1.8 & 21.6 & 1596.4 \\
\hline Ethiopia & 0.8 & 1.2 & 2.0 & 5.5 & 20.6 & 711.0 \\
\hline France & 2.4 & 0.7 & 3.7 & 0.8 & 21.2 & 1369.0 \\
\hline Germany & 1.4 & 0.2 & 3.4 & 0.6 & 24.8 & 1292.6 \\
\hline India & 13.8 & 4.7 & 1.4 & 5.8 & 14.7 & 906.2 \\
\hline Iran & 3.1 & 0.1 & 3.1 & 3.6 & 13.4 & 704.2 \\
\hline Kazakhstan & 5.3 & 0.1 & 5.2 & 2.9 & 41.5 & 151.2 \\
\hline Morocco & 1.3 & 0.1 & 3.3 & 2.0 & 52.0 & 637.6 \\
\hline Poland & 1.1 & 0.3 & 2.0 & 0.5 & 26.4 & 794.9 \\
\hline Romania & 1.0 & 1.3 & 0.9 & 5.1 & 42.5 & 1105.2 \\
\hline Russia & 12.3 & 1.2 & 16.4 & 3.0 & 34.2 & 366.7 \\
\hline Spain & 1.0 & 0.2 & 5.4 & 1.6 & 37.3 & 887.1 \\
\hline the USA & 7.5 & 17.1 & 1.7 & 1.4 & 16.6 & 1209.6 \\
\hline Turkey & 3.4 & 0.3 & 5.4 & 1.1 & 18.6 & 594.9 \\
\hline Ukraine & 3.1 & 2.4 & 5.2 & 5.4 & 26.6 & 785.6 \\
\hline
\end{tabular}

Source: own calculation based on FAOStat (2020) 


\begin{tabular}{|c|c|c|c|c|c|c|}
\hline \multirow{2}{*}{ Country } & \multicolumn{3}{|c|}{ Share $(\%)$ in the World Farmland under } & \multirow{2}{*}{$\begin{array}{c}\text { Expected } \\
\text { Portfolio } \\
\text { Revenue (\%) }\end{array}$} & \multirow{2}{*}{$\begin{array}{c}\text { Portfolio Risk } \\
\qquad(\%)\end{array}$} & \multirow{2}{*}{$\begin{array}{c}\text { Present } \\
\text { Portfolio } \\
\text { Revenue (\$/ha) }\end{array}$} \\
\hline & Sunflower & Soybeans & Rapeseed & & & \\
\hline Argentina & 6.3 & 13.1 & 0.0 & 2.3 & 21.3 & 829.1 \\
\hline Canada & 0.1 & 2.0 & 24.3 & 3.1 & 20.5 & 883.1 \\
\hline China & 3.3 & 6.4 & 17.4 & 3.0 & 15.0 & 1244.6 \\
\hline France & 2.1 & 0.1 & 4.3 & 1.7 & 18.5 & 1119.2 \\
\hline India & 1.0 & 9.1 & 17.8 & 4.4 & 19.5 & 722.5 \\
\hline Kazakhstan & 3.2 & 0.1 & 1.0 & 8.1 & 24.8 & 301.4 \\
\hline Romania & 3.8 & 0.1 & 1.7 & 8.7 & 32.8 & 980.9 \\
\hline Russia & 29.8 & 2.2 & 4.0 & 6.1 & 21.2 & 470.0 \\
\hline the USA & 1.9 & 28.5 & 2.1 & 2.9 & 13.9 & 1167.6 \\
\hline Ukraine & 23.1 & 1.4 & 2.8 & 7.2 & 16.3 & 814.8 \\
\hline
\end{tabular}

Source: own calculation based on FAOStat (2020)

Table 2: Evaluation of oilseeds portfolios by top countries.

\section{Revenue forecast}

As of 2019 , Ukraine ranked the $6^{\text {th }}, 3^{\text {rd }}, 4^{\text {th }}, 1^{\text {st }}, 6^{\text {th }}$, and $3^{\text {rd }}$ among the world top exporters of wheat, maize, barley, sunflower oil, soybeans, and rapeseed. These achievements are essential incentives to delve deeper into improving production portfolios of cereals and oilseeds at the national scope.

The data of six time-series to the task 2 were the revenues (in $\$$ per hectare) from the explored crops delivered by the State Statistics Service of Ukraine (2020) for 1996 to 2019. Hereafter it meant that . The coefficients of the regressions (4) for wheat, maize, barley, sunflower, soybeans, and rapeseed were found by means of the least squares method (5) and assembled in Table 3.

These findings combined and expanded econometric models developed separately for crop prices by Vasylieva (2013) and for yields by Arunachalam and Balakrishnan (2012). As it can be seen from Table 3, all considered cereals and oilseeds had upward revenue trends. The coefficient identified the least annual increase in the revenue for barley and the highest growth in the revenue for rapeseed. Oilseeds appeared to be more uniform by the range of the forecasted revenues for 2020. According to the coefficients $A_{2}$, cereals had more stable revenues except for maize. In all cases, the values of R-squared and F-significance permitted applying the forecasted crop revenues to the next stage of this study concerning the optimal production portfolios for cereals and oilseeds in Ukraine.

\section{Portfolio optimization}

As mentioned before, the calculations to the task 3 stipulated $N=3$ and $T=23$. Given the biodiversity encouragement, parameters $S_{1}, S_{2}$ and $S_{3}$ accounted for 0.05 that implied allocating of at least $5 \%$ of farmland under each crop in an appropriate portfolio. The conducted calculations were linked with four the most beneficial scenarios. Namely,

- scenario \#1 supposed portfolio production with the risk below its current level in Ukraine, to wit, $P R_{\max }=0.266$ for cereals (see Table 1) and $P R_{\max }=0.163$ for oilseeds (see Table 2) in the model (6)-(8);

- scenario \#2 addressed portfolio production without restrictions to the risk level, i.e. running the reduced model (6), (7) for both groups of crops in question;

- scenario \#3 suggested portfolio production with the expected revenue over its current level in Ukraine, to wit, $E P R_{\text {min }}=0.054$ for cereals (see Table 1) and $E P R_{\text {min }}=0.072$ for oilseeds (see Table 2) in the model (9)-(11);

- scenario \#4 defined portfolio production without restrictions to the expected revenue level, i.e. running the reduced model (9), (10) for both groups of crops in question.

The computed figures were aggregated in Tables 4 and 5. Their analysis resulted in the following inferences. 


\begin{tabular}{|c|c|c|c|c|c|c|c|c|}
\hline Crop & $\mathrm{A}_{0}$ & $\mathrm{~A}_{1}$ & $\mathrm{~A}_{2}$ & $\mathrm{~A}_{3}$ & $\mathrm{~A}_{4}$ & R-squared & F-significance & $\begin{array}{c}\text { Revenue } \\
\text { Forecast } \\
\text { for } 2020(\$ / \\
\text { ha) }\end{array}$ \\
\hline \multicolumn{9}{|l|}{ Cereals } \\
\hline Wheat & 95.41 & 23.09 & 60.10 & -0.55 & 1.16 & 0.87 & 0.00 & 658 \\
\hline Maize & 52.56 & 42.57 & 135.97 & 1.45 & 0.39 & 0.88 & 0.00 & 987 \\
\hline Barley & 39.77 & 19.00 & 51.22 & -0.10 & 1.16 & 0.86 & 0.00 & 487 \\
\hline \multicolumn{9}{|l|}{ Oilseeds } \\
\hline Sunflower & -9.29 & 34.51 & 113.88 & 1.63 & -0.37 & 0.95 & 0.00 & 744 \\
\hline Soybeans & 66.32 & 34.16 & 88.21 & 2.21 & -0.40 & 0.91 & 0.00 & 833 \\
\hline Rapeseed & -7.89 & 46.55 & 120.90 & 1.33 & -0.37 & 0.94 & 0.00 & 1035 \\
\hline
\end{tabular}

Source: own calculation based on State Statistics Service of Ukraine (2020)

Table 3: Output to regressions on crop revenue.

\begin{tabular}{lccc|cc}
\hline \multirow{2}{*}{ Scenario } & \multicolumn{2}{c|}{ Share (\%) in the World Farmland under } & Expected Portfolio \\
\cline { 2 - 4 } & Wheat & Maize & Barley & Portfolio Risk (\%) \\
\hline$\# 1$ & 35 & 59 & 6 & 5.5 & 26.6 \\
$\# 2$ & 5 & 90 & 5 & 5.9 & 30.5 \\
$\# 3$ & 30 & 63 & 7 & 5.4 & 26.5 \\
$\# 4$ & 25 & 59 & 16 & 4.5 & 24.7 \\
\hline
\end{tabular}

Source: own calculation based on State Statistics Service of Ukraine (2020)

Table 4: Optimal portfolios for cereals.

\begin{tabular}{|c|c|c|c|c|c|}
\hline \multirow{2}{*}{ Scenario } & \multicolumn{3}{|c|}{ Share $(\%)$ in the World Farmland under } & \multirow{2}{*}{$\begin{array}{l}\text { Expected Portfolio } \\
\text { Revenue }(\%)\end{array}$} & \multirow{2}{*}{ Portfolio Risk (\%) } \\
\hline & Sunflower & Soybeans & Rapeseed & & \\
\hline$\# 1$ & 38 & 5 & 57 & 7.4 & 16.3 \\
\hline$\# 2$ & 5 & 5 & 90 & 7.8 & 22.4 \\
\hline \#3 & 47 & 5 & 48 & 7.2 & 15.4 \\
\hline$\# 4$ & 48 & 21 & 31 & 6.8 & 14.5 \\
\hline
\end{tabular}

Source: own calculation based on State Statistics Service of Ukraine (2020)

Table 5: Optimal portfolios for oilseeds.

Firstly, both cereals and oilseeds portfolios derived from the scenarios \#2 gravitated to more specialized productions. According to Czyzewski and Smedzik-Ambrozy (2015), similar farmers' strategies may be explained by shifting to the crops with larger revenues, reduced technological costs, and diminished marketing expenditures through the deteriorated biodiversity.

Secondly, both cereals and oilseeds portfolios derived from the scenarios \#4 fostered more diversified productions driven by the farmers' strategic priority to mitigate natural and marketing risks (Lin, 2011).

Thirdly, under scenarios \#1 and \#3 Ukraine retained its positions by EPR and PR ranked 3rd and $13^{\text {th }}$ for cereals (see Tables 1 and 4 ) as well as ranked $3^{\text {rd }}$ twice for oilseeds (see Tables 2 and 5). Scenario \#2 applied to cereals elevated Ukrainian EPR up to $1^{\text {st }}$ rank but decreased its PR by 1 position. Scenario \#4 acted the opposite way. It dropped Ukrainian EPR to $4^{\text {th }}$ rank but lifted its PR up to $10^{\text {th }}$ rank. Under scenarios \#2 and \#4 Ukrainian ranks for oilseeds were constant by EPR but shifted to $8^{\text {th }}$ and $2^{\text {nd }}$ by PR.

Finally, according to PPR Ukrainian portfolio revenues were relatively low in absolute terms ranked $10^{\text {th }}$ out of 20 countries by cereals and $7^{\text {th }}$ out of 10 countries by oilseeds. Sure enough, Ukrainian farmers are price-takers in the global scale and can not influence a marketing risk (Velychko et al., 2019). Nevertheless, it is an unfavorable but not a hopeless situation. 
Ukrainian farmers are able to increase their yields of cereals and oilseeds to reach the levels of the most advanced producers via improved technologies and implemented innovations (Vasylieva and Pugach, 2017). As such, the national agricultural autorities ought to encourage this activity and incentivize biodiversity through the political measures of the permissible financial protection of the domestic cereals and oilseeds growers.

\section{Conclusion}

In sum, the largest portfolio producers cultivate 341 million hectares or $74.7 \%$ of the world farmland under wheat, maize, and barley and 127 million hectares or $67.1 \%$ of the total harvested areas under sunflower, soybeans, and rapeseed. These crops are a cornerstone in providing food, feed and bio-fuel resources. Markowitz indicators unfolded that the top cereals producers were more numerous and less uniform compared to the top oilseeds growers. The latter ones practiced less risky activity with higher expected portfolio revenues. The research insight also revealed that Argentina, Canada, China, France, India, Kazakhstan, Romania, Russia, the USA, and Ukraine run large scale portfolios by both cereals and oilseeds. As of 2019, their combined cultivated area amounted to 388.9 million hectares or $60.2 \%$ of the world farmland under these crops.

A combination of econometric and optimization models appeared to be a relevant mathematical technique to enhance portfolio performance by the world major field crops at a country level. It made possible to alleviate uncertainty in yields and prices triggered by natural and marketing risks intrinsic to agribusiness. The proposed utilization of Markowitz models delivered options on reasonable farmland allocation and biodiversity promotion which are global imperatives of contemporary agriculture. With regard to Ukrainian circumstances, the conducted calculations detected opportunities to decrease portfolio risks and raise expected portfolio revenues for the considered crops.

Taking into account the annual revenue fluctuations in cereals and oilseeds markets, the recommended portfolios need regular updates and amendments that can define a promising avenue for further scientific elaborations.

\section{Corresponding authors}

Natalia Vasylieva, Doctor in Economics, Professor

Department of Information Systems and Technologies, Dnipro State Agrarian and Economic University, 25

Serhiya Yefremova Street, Dnipro, 49600, Ukraine

Phone: +38-098-033-4900,E-mail:VasylievaN@i.ua

ORCID: 0000-0003-4100-0659

\section{References}

[1] Arunachalam, R. and Balakrishnan, V. (2012) "Statistical Modeling for Wheat (Triticum Aestivum) Crop Production", International Journal of Statistics and Applications, Vol. 2, No. 4, pp. 40-46. ISSN 2168-5193, E-ISSN 2168-5215. DOI 10.5923/j.statistics.20120204.03.

[2] Barkley, A. P., Peterson, H. and Shroyer, J. (2010) "Wheat Variety Selection to Maximize Returns and Minimize Risk: An Application of Portfolio Theory", Journal of Agricultural and Applied Economics, Vol. 42, No. 1, pp. 39-55. ISSN 1074-0708, E-ISSN 2056-7405. DOI 10.1017/S107407080000328X.

[3] Broll, U., Welzel, P. and Wong, K. P. (2013) "Price Risk and Risk Management in Agriculture", Contemporary Economics, Vol. 7, No. 2, pp. 17-20. ISSN 2084-0845, E-ISSN 2300-8814. DOI 10.5709/ce.1897-9254.79.

[4] Brummer B., Korn O., Schlusler K. and Jaghdani T. J. (2016) "Volatility in oilseeds and vegetable oils markets: Drivers and spillovers“, Journal of Agricultural Economics, Vol. 67, No. 3, pp. 685-705. E-ISSN 1477-9552. DOI 10.1111/1477-9552.12141.

[5] Brussaard, L., Caron P., Campbell, B., Lipper, L., Rabbinge, R., Babin, D. and Pulleman, M. (2010) "Reconciling biodiversity conservation and food security: scientific challenges for a new agriculture", Current Opinion in Environmental Sustainability, Vol. 2, No. 1-2, pp. 34-42. ISSN 1877-3435. DOI 10.1016/j.cosust.2010.03.007. 
[6] Carver, B. F. (2009) “Wheat: Science and Trade“, Hoboken, New Jersey: Wiley-Blackwell, 616 p. ISBN 978-0813820248.

[7] Czyzewski, A. and Smedzik-Ambrozy, K. (2015) "Specialization and diversification of agricultural production in the light of sustainable development", Journal of International Studies, Vol. 8, No 2, pp. 63-73. ISSN 2071-8330, E-ISSN 2306-3483. DOI 10.14254/2071-8330.2015/8-2/6.

[8] Danforth, A. T. (2011) "Corn Crop Production: Growth, Fertilization and Yield", Hauppauge, New York: Nova Science Publishers, Inc., 377 p. ISBN 978-1607419556.

[9] Elfson, S. B. (2011) "Barley: Production, Cultivation and Uses", Hauppauge, New York: Nova Science Publishers, Inc., 341 p. ISBN 978-1612097459.

[10] FAOStat (2020) "Data of the Food and Agriculture Organization of the United Nations", Statistics, Feb. 2020. [Online]. Available: http://www.fao.org/faostat/en/\#data [Accessed: 16 Feb. 2020].

[11] Frison, E. A., Cherfas J. and Hodgkin T. (2011) "Agricultural Biodiversity is Essential for a Sustainable Improvement in Food and Nutrition Security“, Sustainability, Vol. 3, No. 1, pp. 238-253. ISSN 2071-1050. DOI 10.3390/su3010238.

[12] Santeramo F. G. and Lamonaca, E. (2019) "On the drivers of global grain price volatility: an empirical investigation", Agricultural Economics - Czech, Vol. 65, No. 1, pp. 31-42. ISSN 0139-570X, E-ISSN 1805-9295. DOI 10.17221/76/2018-AGRICECON.

[13] Greene, W. H. (2007) "Econometric analysis", Upper Saddle River, New Jersey: Pearson Prentice Hall, p. 1216. ISBN 978-0135132456.

[14] Gunstone, F. (2004) "Rapeseed and Canola Oil: Production, Processing, Properties and Uses", Hoboken, New Jersey: Wiley-Blackwell, p. 240. ISBN 978-1405116251.

[15] Haile, M. G., Kalkuhl, M. and von Braun, J. (2016) "Worldwide acreage and yield response to international price change and volatility: a dynamic panel data analysis for wheat, rice, corn, and soybeans", American Journal of Agricultural Economics, Vol. 98, No. 1, pp. 172-190. ISSN 0002-9092, E-ISSN 1467-8276. DOI 10.1093/ajae/aav013.

[16] Johnson, L. A., White, P. J. and Galloway, R. (2015) "Soybeans: Chemistry, Production, Processing, and Utilization", New York City, New York: Academic Press and AOCS Press, 850 p. ISBN 978-1893997646.

[17] Kolm, P. N., Tutuncu, R. and Fabozzi, F. J. (2014) "60 Years of portfolio optimization: Practical challenges and current trends", European Journal of Operational Research, Vol. 234, No. 2, pp. 356-371. ISSN 0377-2217. DOI 10.1016/j.ejor.2013.10.060.

[18] Lin, B. B. (2011) "Resilience in Agriculture through Crop Diversification: Adaptive Management for Environmental Change“, BioScience, Vol. 61, No. 3, pp. 183-193. ISSN 0006-3568, E-ISSN 1525-3244. DOI 10.1525/bio.2011.61.3.4

[19] Markowitz, H. M. (2010) "Portfolio Theory: As I Still See It", Annual Review of Financial Economics, Vol. 2, No. 1, pp. 1-23. E-ISSN 1941-1375. DOI 10.1146/annurev-financial-011110-134602.

[20] Martinez-Force, E., Dunford, N. T. and Salas, J. J. (2015) "Sunflower: Chemistry, Production, Processing, and Utilization", New York City, New York: Academic Press and AOCS Press, 725 p. ISBN 978-1893997943.

[21] Mumey, G., Burden, B. and Boyda, A. (1992) "Measurement of Farm Risk: Alberta Crop Production", Canadian Journal of Agricultural Economics, Vol. 40, No. 1, pp. 71-91. E-ISSN 1744-7976. DOI 10.1111/j.1744-7976.1992.tb03678.x.

[22] Prigent, J.-L. (2007) "Portfolio Optimization and Performance Analysis", London: Chapman and Hall/CRC, p. 456. ISBN 978-1584885788. DOI 10.1201/9781420010930.

[23] Radulescu, M., Radulescu, C. Z. and Zbaganu, G. (2014) "A portfolio theory approach to crop planning under environmental constraints“, Annals of Operations Research, Vol. 219, pp. 243-264. ISSN 0254-5330, E-ISSN 1572-9338. DOI 10.1007/s10479-011-0902-7. 
[24] Ramankutty, N., Mehrabi, Z., Waha, K., Jarvis, L., Kremen, C., Herrero, M., and Rieseberg, L. H. (2018) "Trends in Global Agricultural Land Use: Implications for Environmental Health and Food Security“, Annual Review of Plant Biology, Vol. 69, pp. 789-815. E-ISSN 1545-2123. DOI 10.1146/annurev-arplant-042817-040256.

[25] Rude, J. and An, H. (2015) "Explaining grain and oilseed price volatility: The role of export restrictions“, Food Policy, Vol. 57, No. 11, pp. 83-92. ISSN 0306-9192. DOI 10.1016/j.foodpol.2015.09.002.

[26] Santeramo F. G. and Lamonaca E. (2019) "On the drivers of global grain price volatility: an empirical investigation“, Agricultural Economics - Czech, Vol. 65, No. 1, pp. 31-42. ISSN 0139-570X, E-ISSN 1805-9295. DOI 10.17221/76/2018-AGRICECON.

[27] Skrypnyk, A., Tkachuk, V., Andruschenko, V. and Bukin, E. (2018) "Sustainable development facets: farmland and market demand estimation", Journal of Security and Sustainability Issues, Vol. 7, No. 3, pp. 513-525. ISSN 2029-7017, E-ISSN 2029-7025. DOI 10.9770/jssi.2018.7.3(11).

[28] State Statistics Service of Ukraine (2020) “Agriculture in Ukraine“. Statistics, Feb. 2020. [Online]. Available: http://www.ukrstat.gov.ua/ [Accessed: 12 Feb. 2020].

[29] Studenmund, A. H. (2016) "Using Econometrics: A Practical Guide“, London: Pearson plc., 576 p. ISBN 978-0134182742.

[30] Toth, M., Holubek, I. and Serences, R. (2016) “Applying Markowitz portfolio theory to measure the systematic risk in agriculture", in Proceedings of Conference: International Scientific Days 2016. The Agri-Food Value Chain: Challenges for Natural Resources Management and Society, Slovak University of Agriculture in Nitra, pp. 985-993. DOI 10.15414/isd2016.s12.10.

[31] Vasylieva, N. (2013) "Forecasting of prices in the field of crops growing in Ukraine and regions", Economic Annals-XXI, No. 11-12(2), pp. 26-29. ISSN 1728-6220, E-ISSN 1728-6239.

[32] Vasylieva, N. and Pugach, A. (2017) "Economic assessment of technical maintenance in grain production of Ukrainian agriculture", Bulgarian Journal of Agricultural Science, Vol. 23, No. 2, pp. 198-203. ISSN 1310-0351, E-ISSN 2534-983X.

[33] Vasylieva, N. (2018) "Ukrainian Agricultural Contribution to the World Food Security: Economic Problems and Prospects“, Montenegrin Journal of Economics, Vol. 14, No. 4, pp. 215-224. ISSN 1800-5845, E-ISSN 1800-6698. DOI 10.14254/1800-5845/2018.14-4.15.

[34] Vasylieva, N. (2019) "Problems and Prospects of Food Security in Ukraine", Bulgarian Journal of Agricultural Science, Vol. 25, No. 4, pp. 668-676. ISSN 1310-0351, E-ISSN 2534-983X.

[35] Velychko, O., Velychko, L., Butko, O. and Khalatur, S. (2019) "Modelling of strategic managerial decisions in the system of marketing logistics of enterprise“, Innovative Marketing, Vol. 15, No. 2, pp. 58-70. ISSN 1814-2427, E-ISSN 1816-6326. DOI 10.21511/im.15(2).2019.05.

[36] Villanueva, A. B., Halewood, M. and Noriega, I. L. (2017) "Agricultural Biodiversity in Climate Change Adaptation Planning“", European Journal of Sustainable Development, Vol. 6, No. 2, pp. 1-8. ISSN 2239-5938, E-ISSN 2239-6101. DOI 10.14207/ejsd.2017.v6n2p1. 